\title{
Determinants of acquisition and failure: Stylized facts and lessons for empirical studies
}

\author{
JENS KÖKE* \\ Centre for European Economic Research \\ Mannheim, Germany
}

May 2001

\begin{abstract}
This study provides new stylized facts on the determinants of corporate failure and acquisition in Germany. It also offers important lessons for the design of empirical studies. We show that firms experiencing failure or acquisition are significantly different from surviving firms on a number of firm-specific characteristics, however the characteristics are similar for failing and acquired firms. This implies that firm failure and acquisition should be analyzed in combination. Second, we find that the industry distribution is significantly different for failure and acquisitions. This calls for some kind of industry-adjustment in empirical analyses. Third, the differences between surviving and failing (acquired) firms are similar, irrespective whether the respective firm characteristic is observed one or up to four or more years before failure (acquisition). This validates the findings of studies that use lags of only one year for explanatory variables.
\end{abstract}

Keywords: Corporate governance, ownership structure, bankruptcy, acquisitions JEL classification: G32, G33, G34

* Corresponding author: Jens Köke, Centre for European Economic Research, Department of International Finance and Financial Management, P.O. Box 1034 43, 68034 Mannheim, Germany; phone: ++49/621/1235-190, fax: $++49 / 621 / 1235-223$, email: koeke@zew.de

Acknowledgements: Financial support from the German Science Foundation (DFG) is gratefully acknowledged (grant no. BO 934, 71). Comments from Axel Börsch-Supan, Peter Westerheide, and Joachim Winter are highly appreciated. Matthias Braun, Gregor Führich, Timo Gieb, and Heiko Truppel provided excellent research assistance. 


\section{Non-technical summary}

This study provides new stylized facts on the determinants of corporate acquisition and failure in Germany. In that course, it has important implications for the design of empirical studies. In particular, we identify which firm-specific characteristics are helpful to explain corporate acquisition and failure, and which measures of these characteristics have the highest explanatory power. We also examine to what extent the length of the forwardlooking time horizon affects the usefulness of our explanatory variables. But we do not examine these issues in a multivariate framework.

The analysis is based on a sample of about 1,700 medium-sized and large German firms for the years 1986-1995. We include listed as well as non-listed firms. Evidence based on descriptive statistics identifies specific firm characteristics that are useful to explain acquisition and failure. Among these are performance, capital structure, ownership concentration, ownership complexity, restructuring activity, and firm size. In addition, information on the type of the ultimately controlling shareholder turns out to be important.

This study has important implications for the design of empirical studies explaining corporate failure or acquisition. First, failure and acquisition typically are the two main reasons for sample attrition in empirical studies, and they appear to be influenced by common factors. Hence, they should be examined in combination. Second, we find that the industry distribution is significantly different for failure and acquisitions. This calls for some kind of industry adjustment in the empirical analysis, for example by including industry dummies or by correcting some variables for their industry benchmark. Third, a range of firm-specific characteristics is helpful to explain failure and acquisition. Analyses leaving out some of these measures are potentially subject to the classical omitted variables problem. Fourth, care should be taken when selecting specific measures for these firm characteristics because some measures perform much better than others in the analysis of firm exit. Finally, the good news is that the length of the forward-looking time horizon essentially does not seem to matter for the usefulness of our measures. This implies that regression models using short lags should capture the main effects. 


\section{Introduction}

The determinants of corporate acquisition and failure have recently attracted the increased attention of researchers and policy-makers alike. In Germany, but also in other Continental European countries the number of insolvencies continued to rise or stagnated at high levels. At the same time, in the past decade we have seen an upsurge in merger and acquisitions activity, both within and across the borders. In Germany and in other Continental European countries, hostile takeovers are rare (Franks and Mayer, 1998). But similarly to the US, registered block trades occur more frequently than tender offers (see Barcley and Holderness, 1991, and Bethel et al., 1998, for the US; see Franks and Mayer, 1994, and Köke, 2000, for Germany; see Renneboog, 2000, for Belgium). In Germany, the repeal of the corporate capital gains tax on sales of cross-shareholdings, coming into effect in the year 2002, is expected to stimulate the market for large share blocks even further. However, especially German policy-makers often argue that acquisitions occur to the detriment of shareholders and other stakeholders. A recent example is the takeover of Mannesmann by the British telecom company Vodafone that provoked intense discussions on the merits of acquisitions.

The intention of this study is to provide new stylized facts on the determinants of corporate acquisition and failure in medium-sized and large German firms. This is important for several reasons. First, previous empirical studies for Germany focus on small firms (e.g., Wagner, 1999; Almus, 2000). Second, most previous empirical studies for Germany (e.g., Harhoff et al., 1998), but also for other countries (e.g., Altman, 1968) do not examine failure and acquisition in combination, although both can be regarded as two forms of market exit. Third, previous research typically concentrates on performance, financial pressure, and firm size as determinants of acquisition and failure (e.g., Powell, 1997; Bethel et al., 1998). We extend this list by considering corporate restructuring as well as detailed ownership characteristics, for example the type of the ultimate owner or ownership complexity. Fourth, we know very little about how these different firm-specific characteristics are best to be measured. Therefore, we investigate a range of variables for each characteristic. Finally, in contrast to standard bankruptcy and merger models we do not only focus on the year prior to exit because this would introduce a selection bias, as argued by Shumway (2001). Rather, we examine different forward-looking time horizons, ranging from one year to four or more years, to see to what extent results in a multivariate framework are likely to depend on the length of this time horizon.

Besides offering a number of stylized facts on corporate acquisition and failure in Germany, this study also serves as a guideline for future empirical research. We explicitly point out which variables are likely to be useful and which time horizon to consider in studies of acquisition and failure. Therefore, the analysis is kept simple and uses descriptive statistics only. For a first application of our findings in a multivariate framework see Heiss and Köke (2001).

The analysis is based on a sample of almost 1,700 medium-sized and large listed as well as non-listed German companies for the years 1986-1995. As firm characteristics helpful to explain failure we identify accounting performance (measured as industry-adjusted returnon-assets or total factor productivity), financial pressure (debt-to-assets ratio), firm size (total assets), layoff activity (growth rate of employment), as well as concentration and complexity of ownership. For acquisitions, the same characteristics are useful, with the exception of layoffs and membership in pyramids as one measure of ownership complexi- 
ty. We also find that information on the type of the ultimately controlling shareholder is likely to be related to the incidence of acquisition and failure. Regarding the length of the forward-looking time horizon, we find that typically the differences in firm-specific characteristics between surviving, failing, and acquired firms persist, irrespective whether the time horizon is one year or up to four or more years. Hence, the usefulness of explanatory variables does not vary much with the length of the time horizon.

We proceed as follows. Section 2 provides a short overview to the theoretical and empirical literature on the determinants of acquisition and failure. The literature is condensed into a set of hypotheses to guide the descriptive analysis in Section 4. Section 3 describes the data used in this study. Section 4 compares the industry distribution of firms that fail or are acquired, and it compares these firms with surviving firms on important firm-specific characteristics. Section 5 summarizes the main findings, formulates new stylized facts on acquisition and failure, and concludes with some lessons for the design of empirical studies.

\section{Hypotheses}

To guide our search for firm-specific characteristics that determine acquisition and failure, we formulate a set of hypotheses building on the theoretical and empirical literature. The first set of hypotheses concentrates on factors that make failure and acquisition more likely to occur. These are poor performance and high financial pressure, but also restructuring activity as an indicator of the ongoing need to adapt operations.

Hypothesis A1: Acquisitions are more likely for firms with poor performance.

Hypothesis F1: Failures are more likely for firms with poor performance.

Hypothesis A2: Acquisitions are more likely for firms with high financial pressure.

Hypothesis F2: Failures are more likely for firms with high financial pressure.

Hypothesis A3: Acquisitions are more likely for firms that undergo severe restructuring.

Hypothesis F3: Failures are more likely for firms that undergo severe restructuring.

The current theoretical view of control transfers is largely shaped by two conflicting effects of blockholder control (Kahan, 1993; Bebchuk, 1994). On the one hand, transferring control to a more effective management team could improve efficiency. On the other hand, the acquirer's primary motive may be to loot the firm to the detriment of small shareholders. Empirical evidence suggests that block trades lead to efficiency gains (Barcley and Holderness, 1991). Similarly, evidence on the aftermath of block purchases suggests that they bring about improvements. For the US, Bethel et al. (1998) report that activist block purchases are followed by significant operational changes, increased CEO turnover, and improvements in profitability. For the UK, Franks et al. (1999) document increased board turnover in poorly performing firms after a block purchase. For Germany, Köke (2000) finds that control transfers are followed by increased managerial turnover as well as improvements in profitability and productivity of poorly performing firms. Denis and Sarin (1999) and Maksimovic and Phillips (2000) provide empirical evidence for the US that firms with poor performance are more likely to be takeover targets. In summary, we expect poor performance to be related to a higher probability of takeover (Hypothesis 
A1). Concerning firm failure, a number of studies suggests that performance is useful to explain firm failure (see, e.g., Altman, 1968; Powell, 1997; Astebro and Winter, 2001). In short, we expect that firms are more likely to fail when performance is poor (Hypothesis F1).

Related to performance is the capital structure as a determinant of firm failure or changes in ownership. Mitchell and Mulherin (1996) argue that economic shocks to an industry can alter the allocation of resources within the firm. In turn, changes in the firm's growth opportunities, leverage, or firm size could make adjustments in ownership necessary. Consistent with this view, Zingales (1998) reports that following deregulation in the US trucking industry in 1977 firms were confronted with increasing leverage, and that this has lead to a higher probability of market exit. Other empirical studies on firm failure confirm this role of financial pressure (Altman, 1968; Powell, 1997). Hence, we expect that firms with higher financial pressure are more likely to be takeover targets or candidates for failure (Hypotheses A2 and F2).

Restructuring activity could also explain firm failure. If a firm starts a restructuring program, for example by laying off employees or selling assets after financial difficulties became obvious, then restructuring could serve as an indicator that the firm firm has been or still is in the need of reorganization. Almus (2000) provides evidence for small German firms that failing firms show stagnation or reductions in employment already several years before final failure. Hence, ongoing restructuring activity could represent either first indicators of failure (Hypothesis F3) or difficulties that need to be resolved by a new owner of the distressed firm (Hypothesis A3).

The second set of hypotheses concentrates on factors that make failure or acquisition less likely to occur. These encompass ownership concentration, ownership complexity, and firms size.

Hypothesis A4: Acquisitions are less likely for firms with very high and very low concentration of ownership.

Hypothesis F4: Failures are less likely for firms with high concentration of ownership.

Hypothesis A5: Acquisitions are less likely for firms with complex ownership structures.

Hypothesis F5: Failures are less likely for firms with complex ownership structures.

Hypothesis A6: Acquisitions are less likely for large firms.

Hypothesis F6: Failures are less likely for large firms.

Concentration of share ownership could affect the likelihood of firm failure or control transfer. Grossman and Hart (1980) argue that a precondition for hostile takeovers to be effective is concentrated share ownership because under a dispersed ownership structure shareholders would prefer to free-ride. In consequence, no takeover would take place in widely held firms. Burkart et al. (2000) show that the incumbent and new controlling shareholder prefer to trade the block rather than sell shares to the public and, in a second step, accumulate those dispersed shares because they anticipate the free-riding behavior of small shareholders in tender offers. Hence, an ex ante larger concentration of shares should make block transfers more likely. In contrast, Holmström and Tirole (1993) argue that takeovers require low concentration of ownership and, in turn, high market liquidity because only then are capital markets able to determine the necessity of a takeover. The 
few cases of hostile takeovers in Germany support Holmström and Tirole: In all cases the shares of the takeover target were widely dispersed (Franks and Mayer, 1998). However, the significant number of non-hostile control transfers in Germany indicates that block trades occur also in the presence of large share concentration, which is typical for German companies (Köke, 2000; Jenkinson and Ljungqvist, 2001). In sum, we expect the costs of a takeover to be the largest for both very high and very low concentration of share ownership (Hypothesis A4). The implication of share concentration for firm failure is less ambiguous. Higher share concentration implies that the scope for agency conflicts is reduced, and hence large shareholders can alleviate the agency problem via better monitoring (Shleifer and Vishny, 1986). We expect that the likelihood of failure shrinks with ownership concentration (Hypothesis F4).

As to Hypotheses A5 and F5, the complexity of a firm's ownership structure can also be relevant. If a firm is part of a pyramid, management could be more likely to resist control sales because selling parts of a conglomerate would imply a loss of organizational capital. Likewise, pyramids can manifest managerial empires and as such have a value to managers (Franks and Mayer, 1995). We expect that changes in ownership are less likely when the respective firm is part of a pyramid. Similarly, changes in ownership should be less likely if a firm is ultimately controlled by the well-known web of German firms (Adams, 1994; Wenger and Kaserer, 1998). The reason is that cross-ownership can provide target management with an effective anti-takeover device against unwelcome raiders (Bebchuk, et al. 1998). Likewise, we expect failures to be less likely for firms which are part of pyramids or are controlled by cross-owned shareholders. The reason is that complex ownership structures, as represented by pyramids and cross-ownership, could reduce informational asymmetries. Likewise, empire-building could prevent management from closing down firms even in mature industries (Jensen, 1986).

Finally, firm size could deter changes in control (Hypothesis A6) and firm failure (Hypothesis F6). Shleifer and Vishny (1992) argue that the market for corporate control is less liquid as size increases. Another reason might be that the likelihood of a takeover will be lower for large firms due to wealth constraints on the side of the buyer. Bethel et al. (1998) and Mulherin and Boone (2000) provide empirical evidence that smaller firms are more likely to become takeover targets. If firms are very large and if these firms get into financial trouble, this might give management the opportunity to be eligible for help from creditors or the government. A recent example is the case of Holzmann AG, a large German construction conglomerate. After having come into severe financial difficulties, creditors agreed - under the lead of German chancellor Schröder - to extend existing credits to Holzmann AG by another two billion DM.

\section{Data and frequency of exit}

The full sample comprises 6,515 observations from 1,670 listed as well as non-listed German firms for the years 1986-1995. For all firms the data set contains yearly information on performance, capital structure, ownership structure, restructuring activity, and firm size. In addition, it contains information on the industry (two-digit NACE code). The panel is unbalanced in the sense that firms can enter the sample after the year 1986 and exit the sample before 1995, the final year of the sample.

A crucial element of the data set is detailed information on the firms' ownership structure. Ownership information is available for the years 1986-1996. Applying a concept of 
control, which is based on ultimate share ownership (Köke, 2000; see Appendix B), we identify whether a firm in any given year has a dominant shareholder or not. In a second step, based on changes in the name of the so-defined ultimate owner we determine whether a new owner acquires control. For the cases in which balance sheet data time series end before 1996, the last year for which ownership information is available, we evaluate whether this lack of balance sheet data is due to an acquisition or bankruptcy in the year ahead. In sum, we obtain information on the survival status (survival, acquisition, or failure) of all sample firms. Since the last year for which the survival status can be observed is 1996, and since the present analysis focuses on the years prior to a change in control or failure, the sample used for the analysis covers the years 1986-1995.

Note that we consider only cases in which a new owner acquires control, either from the dominant shareholder or from previously dispersed shares. We do not consider cases in which an initially concentrated control block is dissolved because this study focuses on true acquisitions of control. Mello and Parsons (1998) argue that the market for dispersed shareholdings is distinct from the market for control blocks. For empirical evidence that the market for shares is segmented along this line, see Hanley and Wilhelm (1995).

Table 1: Number of firms by reason and year of exit

\begin{tabular}{lrrrr}
\hline \hline Year of sample exit & Survival & Failure & Acquisition & Total \\
\hline 1987 & 0 & 0 & 3 & 3 \\
1988 & 2 & 0 & 19 & 21 \\
1989 & 2 & 0 & 45 & 47 \\
1990 & 3 & 1 & 38 & 42 \\
1991 & 4 & 1 & 22 & 27 \\
1992 & 3 & 3 & 34 & 40 \\
1993 & 10 & 6 & 19 & 35 \\
1994 & 19 & 1 & 52 & 72 \\
1995 & 68 & 16 & 54 & 138 \\
1996 & 1,110 & 3 & 132 & 1,245 \\
\hline Total & 1,221 & 31 & 418 & 1,670 \\
\hline In percent & $73.1 \%$ & $1.9 \%$ & $25.0 \%$ & $100.0 \%$ \\
\hline \hline
\end{tabular}

Notes: Number of firms that exit the sample in a given year due to failure or acquisition (reported in columns failure and acquisition, respectively). Firms that leave the sample but survive (reported in column survival) exit simply due to an interrupted balance sheet data time series. But only those firms are classified as surviving which do not experience failure or acquisition within at least one more year. The last year for which information on the survival status was collected is 1996 .

Table 1 shows how many firms exit from the sample in any one year, together with the reason for exit. In addition, Table 1 provides information in which year the time series of surviving firms end. Out of 1,670 firms the largest majority $(73.1 \%)$ survives. For most surviving firms time series data end in the year 1996. About one hundred surviving firms, though, have shorter time series, ending the earliest in 1988. A small fraction of firms (1.9\%) declares bankruptcy, and a quarter of firms is acquired by another entity. Most cases of failure take place in the year 1995. Likewise, the rate of acquisitions is the highest during the years 1994-1996. One explanation for these high rates of market exit could be that the German economy went through a major recession in the mid 1990s.

The empirical analysis in Sections 4 is based on a full sample (6,515 firm-years), and 
three sub-samples (Table 2). In the full sample, for each firm-year included it is known whether the respective firm still exists in the following year (survival), declares bankruptcy (failure), or is taken over by another entity (acquisition). Hence, the forward-looking time horizon is one year. In the three sub-samples, the number of observations is reduced because the forward-looking time horizon is extended to two years (5,331 firm-years), three years (4,049 firm-years), and four or more years (3,283 firm-years), respectively. The sub-samples include only those observations for which information on the exit status is available for the next two, three, and four or more years. Table 2 summarizes the number of observations used in the empirical analysis, separately for the number of years looking ahead (time horizon).

Table 2: Number of observations by time horizon

\begin{tabular}{lrrrr}
\hline \hline Time horizon & Survival & Failure & Acquisition & Total \\
\hline Within 1 year & 6,066 & 31 & 418 & 6,515 \\
Within 2 years & 4,605 & 54 & 672 & 5,331 \\
Within 3 years & 3,321 & 75 & 653 & 4,049 \\
Within 4 years + & 2,228 & 139 & 916 & 3,283 \\
\hline \hline
\end{tabular}

Notes: Number of firms in a given year that survive, fail, or are acquired within the next year, the next two years, the next three years, or the next for or more years, respectively.

Appendix A contains a detailed description of the data sources used and the procedure applied to construct the sample. Appendix B gives a technical description of the concept of control used to identify the ultimate owner of each sample firm. Appendix $\mathrm{C}$ summarizes the definition of all variables analyzed in this study.

\section{Stylized facts}

In this section, we present detailed descriptive statistics on firm-specific characteristics which are likely to determine failure and acquisition. Our intention is to identify a set of variables that are useful for empirical analyses investigating corporate acquisition and failure. In addition, we check whether the length of the forward-looking time horizon matters when using the identified firm characteristics as explanatory variables in empirical analyses. The hypotheses put forward in Section 2 serve as a guideline for the following analysis. First, we look whether there is significant industry clustering of firms that survive, fail, or are acquired (Section 4.1). In Sections 4.2-4.5 we present descriptive evidence on firm-specific characteristics such as performance, capital structure, ownership structure, restructuring activity, and firm size. And in Section 4.6 we briefly summarize which measures turn out to be helpful as explanatory variables.

\subsection{Industry distribution}

Table 3 shows the industry pattern of surviving, failing, and acquired firms, based on the full sample of 1,670 firms. The largest fraction of sample firms operates in wholesale trade (12.4 percent), machinery (11.3 percent), chemicals (8.6 percent), and food (7.7 percent).

Industries with a comparatively large fraction of failing firms are textiles, clothing, machinery, construction of other vehicles (in particular shipyards), as well as furniture, 
jewelry, and toys. Most of these industries can be regarded as mature industries in which German firms lost competitiveness since years. For acquisitions, we find comparatively high rates of takeover activity for the industries of ore mining, rock and stone mining, textiles, paper, metals, and again furniture, jewelry, and toys.

Table 3: Survival and exit of firms by industry

\begin{tabular}{|c|c|c|c|c|}
\hline Industry (Two-digit NACE code) & Survival & Failure & Acquisition & Number of firms \\
\hline Coal mining (10) & $100.0 \%$ & $0.0 \%$ & $0.0 \%$ & 8 \\
\hline Oil and gas extraction (11) & $100.0 \%$ & $0.0 \%$ & $0.0 \%$ & 17 \\
\hline Ore mining (13) & $50.0 \%$ & $0.0 \%$ & $50.0 \%$ & 4 \\
\hline Rock and stone mining (14) & $50.0 \%$ & $0.0 \%$ & $50.0 \%$ & 12 \\
\hline Food $(15)$ & $76.6 \%$ & $1.6 \%$ & $21.9 \%$ & 128 \\
\hline Tobacco $(16)$ & $100.0 \%$ & $0.0 \%$ & $0.0 \%$ & 7 \\
\hline Textiles (17) & $39.1 \%$ & $10.9 \%$ & $50.0 \%$ & 46 \\
\hline Clothing (18) & $68.8 \%$ & $6.3 \%$ & $25.0 \%$ & 16 \\
\hline Leather (19) & $66.7 \%$ & $0.0 \%$ & $33.3 \%$ & 6 \\
\hline Wood $(20)$ & $100.0 \%$ & $0.0 \%$ & $0.0 \%$ & 5 \\
\hline Paper (21) & $47.2 \%$ & $2.8 \%$ & $50.0 \%$ & 36 \\
\hline Publishing and printing (22) & $87.5 \%$ & $0.0 \%$ & $12.5 \%$ & 16 \\
\hline Coal and oil processing (23) & $85.7 \%$ & $0.0 \%$ & $14.3 \%$ & 21 \\
\hline Chemicals $(24)$ & $84.6 \%$ & $0.0 \%$ & $15.4 \%$ & 143 \\
\hline Rubber and plastic products $(25)$ & $74.2 \%$ & $0.0 \%$ & $25.8 \%$ & 62 \\
\hline Rock, stone, glass (26) & $61.7 \%$ & $1.7 \%$ & $36.7 \%$ & 60 \\
\hline Metals (27) & $59.5 \%$ & $1.4 \%$ & $39.2 \%$ & 74 \\
\hline Metal products (28) & $63.4 \%$ & $2.8 \%$ & $33.8 \%$ & 71 \\
\hline Machinery $(29)$ & $70.7 \%$ & $4.8 \%$ & $24.5 \%$ & 188 \\
\hline Machines for data processing (30) & $73.7 \%$ & $2.6 \%$ & $23.7 \%$ & 38 \\
\hline Machines for power generation (31) & $74.0 \%$ & $2.0 \%$ & $24.0 \%$ & 50 \\
\hline $\begin{array}{l}\text { Machines for broadcasting } \\
\text { and television }(32)\end{array}$ & $78.0 \%$ & $0.0 \%$ & $22.0 \%$ & 50 \\
\hline $\begin{array}{l}\text { Medical, optical, } \\
\text { and control instruments (33) }\end{array}$ & $74.2 \%$ & $0.0 \%$ & $25.8 \%$ & 31 \\
\hline Cars and car parts (34) & $72.0 \%$ & $2.0 \%$ & $26.0 \%$ & 50 \\
\hline Other vehicles $(35)$ & $69.8 \%$ & $4.7 \%$ & $25.6 \%$ & 43 \\
\hline Furniture, jewelry, toys (36) & $46.2 \%$ & $7.7 \%$ & $46.2 \%$ & 13 \\
\hline Recycling (37) & $66.7 \%$ & $0.0 \%$ & $33.3 \%$ & 3 \\
\hline Construction (45) & $85.1 \%$ & $1.4 \%$ & $13.5 \%$ & 74 \\
\hline Trade of cars and car parts (50) & $81.0 \%$ & $0.0 \%$ & $19.0 \%$ & 21 \\
\hline Wholesale trade $(51)$ & $79.7 \%$ & $0.5 \%$ & $19.8 \%$ & 207 \\
\hline Retail trade $(52)$ & $79.4 \%$ & $0.0 \%$ & $20.6 \%$ & 34 \\
\hline Hotel and restaurant (55) & $66.7 \%$ & $0.0 \%$ & $33.3 \%$ & 9 \\
\hline Diversified holding companies (74) & $71.7 \%$ & $0.8 \%$ & $27.6 \%$ & 127 \\
\hline Average & $73.1 \%$ & $1.9 \%$ & $25.0 \%$ & 1,670 \\
\hline
\end{tabular}

Notes: Fraction of firms by industry that survive, are acquired, or fail at a one-year horizon. Fractions of firms add to 100 percent by industry.

These simple statistics indicate that the determinants of firm failure and acquisition are likely to be different because industry clustering for failures is different from industry clustering for acquisitions. This implies that any analysis of market exit of firms should 
distinguish between failure and acquisition as two different forms of market exit. Secondly, these figures suggest that both, firm failure and acquisition, have a strong industry-specific component. For regression analyses examining firm exit this calls for some kind of industry adjustment, for example by including industry dummies or by correcting firm-specific variables with the respective industry benchmark.

\subsection{Performance}

Table 4 shows how performance of surviving firms compares to performance of failing and acquired firms. Mean (columns 1-3) and median (columns 4-6) statistics are calculated for different time horizons, ranging from looking one year ahead to looking four or more years ahead. The reason for calculating firm-specific characteristics for different time horizons is that ex ante it is unknown whether a particular firm fails, for example, within the next year or not, within the next two years or not, and so on. In a realistic situation, it is typically more interesting, for example from the perspective of a banker, whether a firm survives the next x years, or not (Astebro and Winter, 2001). Knowing when exactly within these $\mathrm{x}$ years a firm fails is a more complicated problem, and presumably only of second order to a banker. All performance measures are industry-adjusted in the sense that they represent the difference to median performance at the two-digit industry level. ${ }^{1}$ Productivity is corrected for mean productivity in the same two-digit industry. Annual stock market return is adjusted for performance of the DAFOX, which is the size-weighted return of all German stocks.

We find strong support for Hypothesis F1. Table 4 shows that performance of failing firms is significantly worse than performance of surviving firms. This result holds irrespective whether based on accounting measures such as return-on-assets (ROA), returnon-equity (ROE), return-on-sales (ROS), or whether based on total factor productivity or stock market return. Interestingly, performance of failing firms is also significantly worse than performance of surviving firms, irrespective which time horizon is used. For example, industry-adjusted total factor productivity of firms that fail within a time window of the next three years (-35.2 percent) is significantly worse than productivity of firms that survive at least three more years (-5.8 percent). The only difference between the four time horizons is that the market-based measures, i.e. annual stock market returns and the market-to-book ratio, for failing firms are not significantly different from those of surviving firms with a time window of one or two years.

Similarly, Hypothesis A1 is also strongly supported. We find that acquired firms perform significantly worse than surviving firms (Table 4). This result holds when performance is based on accounting measures and productivity, but not when based on market measures. In general, performance of failing firms is several times worse than performance of acquired firms. For example, firms that fail within one year show an average industryadjusted ROA of -9.3 percent, but firms that are acquired an industry-adjusted ROA of -0.5 percent. With a time horizon of four years and above, the difference in performance between failing and acquired firms is significantly different from zero at the one-percent level, irrespective of the performance measure chosen (not tabled).

1 We also compared accounting performance without industry-adjustment. The obtained results were similar in quality and in relative magnitude. 
Table 4: Industry-adjusted performance as determinant of exit

\begin{tabular}{|c|c|c|c|c|c|c|c|}
\hline & \multicolumn{3}{|c|}{ Mean } & \multicolumn{3}{|c|}{ Median } & \multirow{2}{*}{$\begin{array}{r}\text { Number } \\
\text { of obs. }\end{array}$} \\
\hline & Survival & Failure & Acquisition & Survival & Failure & Acquisition & \\
\hline $\begin{array}{l}\text { Return-on-assets } \\
\text { within } 4 \text { years }+ \\
\text { within } 3 \text { years } \\
\text { within } 2 \text { years } \\
\text { within } 1 \text { year }\end{array}$ & $\begin{array}{l}2.1 \% \\
1.4 \% \\
1.2 \% \\
0.9 \%\end{array}$ & $\begin{array}{l}-3.0 \% \text { *** } \\
-4.9 \% \text { *** } \\
-5.2 \% \text { *** } \\
-9.3 \% \text { *** }\end{array}$ & $\begin{array}{l}0.6 \% * * * \\
0.2 \% * * \\
-1.0 \% * * * \\
-0.5 \% * *\end{array}$ & $\begin{array}{l}1.5 \% \\
1.0 \% \\
0.7 \% \\
0.5 \%\end{array}$ & $\begin{array}{l}-0.8 \% \text { *** } \\
-3.5 \% \text { *** } \\
-3.1 \% \text { *** } \\
-4.4 \% \text { *** }\end{array}$ & $\begin{array}{c}0.5 \% \text { *** } \\
0.1 \%^{* * *} \\
-0.5 \% \text { *** } \\
-0.5 \% \text { *** }\end{array}$ & $\begin{array}{l}3,283 \\
4,049 \\
5,331 \\
6,515\end{array}$ \\
\hline $\begin{array}{l}\text { Return-on-equity } \\
\text { within } 4 \text { years }+ \\
\text { within } 3 \text { years } \\
\text { within } 2 \text { years } \\
\text { within } 1 \text { year }\end{array}$ & $\begin{array}{l}3.3 \% \\
2.4 \% \\
2.8 \% \\
2.4 \%\end{array}$ & $\begin{array}{c}-5.5 \% \text { *** } \\
-11.5 \% * * * \\
-14.7 \% \text { *** } \\
-28.7 \% \text { *** }\end{array}$ & $\begin{array}{l}1.2 \%^{* *} \\
1.0 \% \\
-2.7 \%^{* * *} \\
-1.5 \%^{* *}\end{array}$ & $\begin{array}{l}1.4 \% \\
0.9 \% \\
0.7 \% \\
0.4 \%\end{array}$ & $\begin{array}{l}-1.4 \% \text { *** } \\
-4.6 \% \text { *** } \\
-4.8 \% \text { *** } \\
-6.3 \% \text { *** }\end{array}$ & $\begin{array}{l}0.4 \%^{* * *} \\
-0.2 \%^{* *} \\
-1.2 \%^{* * *} \\
-0.9 \%^{* *}\end{array}$ & $\begin{array}{l}3,283 \\
4,049 \\
5,331 \\
6,515\end{array}$ \\
\hline $\begin{array}{l}\text { Return-on-sales } \\
\text { within } 4 \text { years }+ \\
\text { within } 3 \text { years } \\
\text { within } 2 \text { years } \\
\text { within } 1 \text { year }\end{array}$ & $\begin{array}{l}5.4 \% \\
4.4 \% \\
4.1 \% \\
3.6 \%\end{array}$ & $\begin{array}{l}-2.5 \% \text { *** } \\
-5.9 \% \text { ** } \\
-6.3 \% \text { *** } \\
-8.9 \% \text { *** }\end{array}$ & $\begin{array}{l}2.3 \% * * * \\
1.2 \% * * * \\
1.0 \% * * * \\
2.6 \%\end{array}$ & $\begin{array}{l}1.0 \% \\
0.7 \% \\
0.5 \% \\
0.3 \%\end{array}$ & $\begin{array}{l}-0.8 \% \text { *** } \\
-1.9 \% \text { *** } \\
-1.8 \% \text { *** } \\
-3.1 \% \text { *** }\end{array}$ & $\begin{array}{c}0.6 \% \text { *** } \\
0.1 \% \text { *** } \\
-0.3 \% \text { *** } \\
-0.2 \% \text { *** }\end{array}$ & $\begin{array}{l}3,137 \\
3,869 \\
5,111 \\
6,259\end{array}$ \\
\hline $\begin{array}{l}\text { Total factor produ } \\
\text { within } 4 \text { years }+ \\
\text { within } 3 \text { years } \\
\text { within } 2 \text { years } \\
\text { within } 1 \text { year }\end{array}$ & $\begin{array}{r}\text { ctivity } \\
-4.2 \% \\
-5.8 \% \\
-1.7 \% \\
0.6 \%\end{array}$ & $\begin{array}{l}-36.1 \% * * * \\
-35.2 \% * * * \\
-42.2 \% * * * \\
-39.2 \% * * *\end{array}$ & $\begin{array}{l}-14.9 \% * * * \\
-9.0 \% \\
-9.0 \% * * \\
-8.3 \% * *\end{array}$ & $\begin{array}{l}-7.1 \% \\
-8.0 \% \\
-5.3 \% \\
-2.9 \%\end{array}$ & $\begin{array}{l}-29.8 \% * * * \\
-33.7 \% * * * \\
-33.9 \% * * * \\
-34.6 \% * * *\end{array}$ & $\begin{array}{l}-15.3 \%^{* * *} \\
-13.1 \% \\
-11.8 \%^{* *} \\
-9.7 \%^{*}\end{array}$ & $\begin{array}{l}2,918 \\
3,590 \\
4,756 \\
5,851\end{array}$ \\
\hline $\begin{array}{l}\text { Annual stock mar } \\
\text { within } 4 \text { years }+ \\
\text { within } 3 \text { years } \\
\text { within } 2 \text { years } \\
\text { within } 1 \text { year }\end{array}$ & $\begin{array}{r}\text { ket return } \\
1.6 \% \\
0.0 \% \\
0.2 \% \\
-1.9 \%\end{array}$ & $\begin{array}{l}-13.0 \% * * * \\
-18.6 \% * * \\
-29.9 \% * * * \\
-23.0 \%\end{array}$ & $\begin{array}{r}2.0 \% \\
-1.5 \% \\
-1.1 \% \\
-1.8 \%\end{array}$ & $\begin{array}{r}1.1 \% \\
-0.8 \% \\
-0.2 \% \\
-2.1 \%\end{array}$ & $\begin{array}{l}-13.2 \% \text { *** } \\
-16.6 \% * * * \\
-29.3 \% * * * \\
-11.9 \%\end{array}$ & $\begin{array}{r}2.0 \% \\
-0.4 \% \\
-0.1 \% \\
0.5 \%\end{array}$ & $\begin{array}{l}1,343 \\
1,611 \\
1,865 \\
2,106\end{array}$ \\
\hline $\begin{array}{l}\text { Market-to-book-ra } \\
\text { within } 4 \text { years }+ \\
\text { within } 3 \text { years } \\
\text { within } 2 \text { years } \\
\text { within } 1 \text { year }\end{array}$ & $\begin{array}{l}\text { tio } \\
\qquad \begin{array}{l}19.5 \% \\
21.7 \% \\
21.0 \% \\
19.4 \%\end{array}\end{array}$ & $\begin{array}{l}6.5 \% \text { *** } \\
4.5 \% * \\
60.5 \% \\
67.1 \%\end{array}$ & $\begin{array}{l}30.8 \% * * \\
19.8 \% \\
15.6 \% \\
13.5 \%\end{array}$ & $\begin{array}{l}1.4 \% \\
2.0 \% \\
1.3 \% \\
0.1 \%\end{array}$ & $\begin{array}{r}-3.9 \% \\
-10.3 \% \\
-9.2 \% \\
0.2 \%\end{array}$ & $\begin{array}{c}4.3 \% \\
-1.0 \% \\
-1.7 \% * \\
0.7 \%\end{array}$ & $\begin{array}{l}1,198 \\
1,443 \\
1,670 \\
1,891\end{array}$ \\
\hline
\end{tabular}

Notes: Mean and median industry-adjusted performance of firms which survive or exit within the next one to four or more years. The test statistics are heteroskedastic t-tests of equal means (columns 1 vs. 2, and 1 vs. 3) and Wilcoxon rank-sum tests of equal medians (columns 4 vs. 5, and 4 vs. 6). *,**,*** indicates significance at the 10, 5, and 1-percent levels, respectively.

Concerning the question how to measure performance, Table 4 suggests that accountingbased returns, but also market-based returns or productivity estimates can be used to predict firm failure. To determine the likelihood of acquisition, accounting-based and market-based measures appear to have a different impact. The fact that market-based measures do not seem to be related to the likelihood of acquisition could mean that acquisitions do not occur primarily in poorly performing firms. Another interpretation could be that capital markets anticipate the change in control, and an eventual improvement in performance following the foreseeable change in control is already reflected in the market price. Besides, since market-based measures are, of course, available only for 
listed firms, the observed relation of performance and the likelihood for acquisition might also result from a sample selection problem. Due to these theoretical problems related to market-based measures, a saver approach would be to examine (at least additionally) accounting-based measures of performance. Regarding the length of the forward-looking time horizon, the results show that the time horizon does not matter, at least when using accounting-based measures of performance. The most consistent result over all four time horizons is obtained when using industry-adjusted ROA.

\subsection{Capital structure}

Table 5 shows how the capital structure of surviving firms compares to the capital structure of failing and acquired firms. Similar to Table 4, mean (columns 1-3) and median (columns 4-6) statistics are reported for different time horizons, ranging from looking one year ahead to looking four or more years ahead.

Firms that fail face significantly higher financial pressure than firms that survive, irrespective which time horizon we choose and irrespective whether we look at interest coverage or the debt-to-assets ratio (Table 5). For example, firms that fail within one year have a mean debt-to-assets ratio of 61 percent, compared with a ratio of about 42 percent for firms that survive the following year. Likewise, for failing firms median interest coverage is well below the value of two, a level by analysts typically regarded as an indicator of financial distress. These results strongly support Hypothesis F2.

The picture for other measures of financial pressure is less clear. When using the quick ratio, defined as short-term assets less inventory, normalized by short-term liabilities, failing firms are significantly less liquid than surviving firms. Results look weaker when using the working capital ratio, defined as short-term assets less short-term liabilities, normalized by total assets, or when using the ratio of cash-flow-to-assets. But in general, most measures indicate that failing firms face higher financial pressure than surviving firms.

Analogous results are found for acquired firms. The debt-to-assets ratio is significantly higher, and interest coverage as well as the other capital structure measures are significantly lower compared with surviving firms. These results support Hypothesis A2. Another interpretation could be that acquisitions are not (primarily) driven by free-cashflow considerations (Jensen, 1986). For the debt-to-assets ratio and interest coverage, the difference between failing and acquired firms is significantly different from zero at the one-percent level, but generally not for the other measures (not tabled).

Concerning the question how to measure financial pressure, Table 5 suggests that the choice of a particular measure is likely to influence regression results much more than the choice of a particular measure for performance. However, the direction of the expected effect is the same across all different measures. Considering the length of the time horizon, we find that the debt-to-assets ratio and interest coverage yield the most consistent results across all four time horizons. Therefore and because most other measures are based on a somewhat smaller number of observations we consider the debt-to-assets ratio and interest coverage as the preferred measures for empirical analyses. In fact, one or both of these measures are commonly used in the literature. 
Table 5: Capital structure as determinant of exit

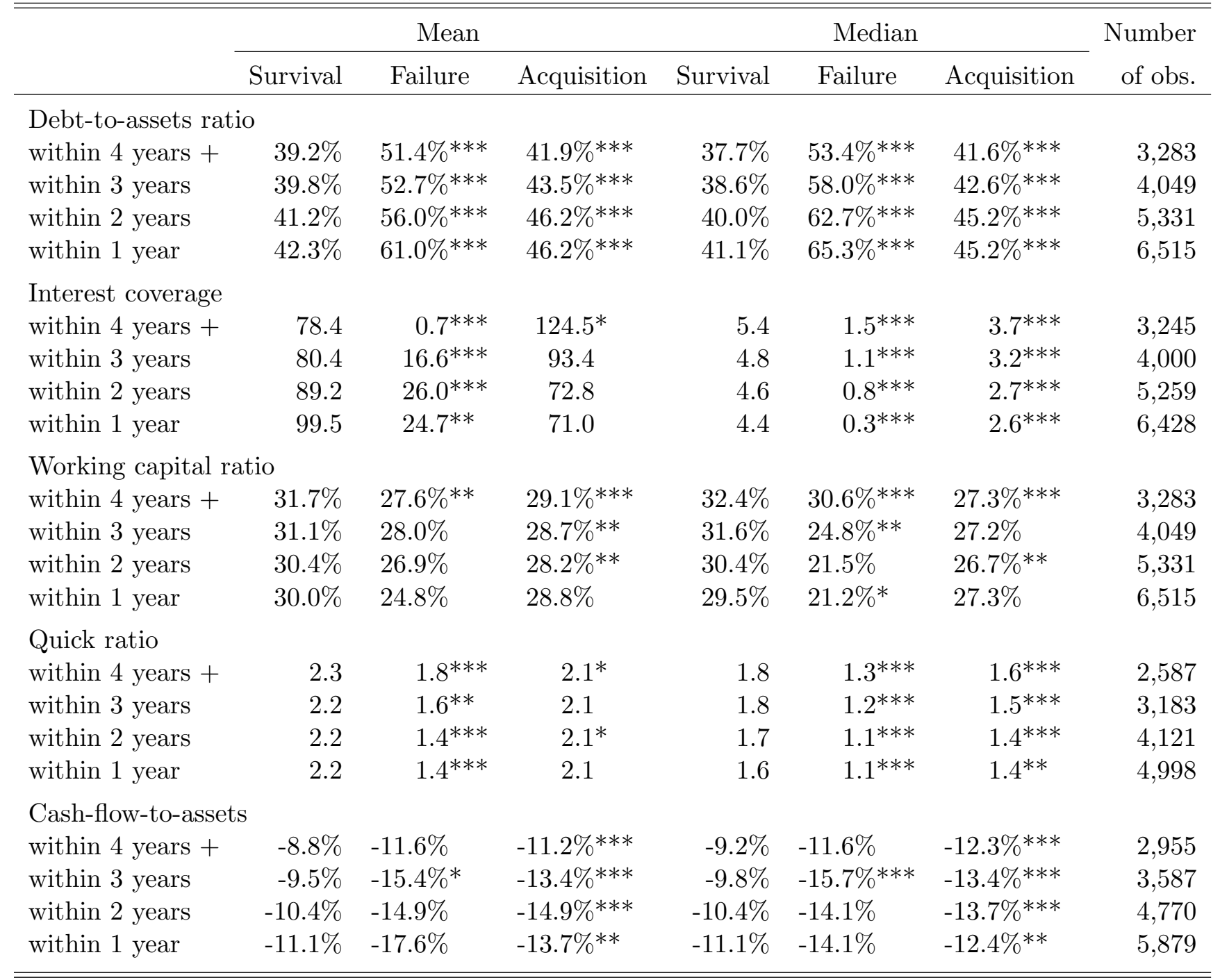

Notes: Mean and median values of capital structure measures, calculated for firms which survive or exit within the next one to four or more years. The test statistics are heteroskedastic t-tests of equal means (columns 1 vs. 2 , and 1 vs. 3 ) and Wilcoxon rank-sum tests of equal medians (columns 4 vs. 5 , and 4 vs. 6). ${ }^{*},{ }^{*},{ }^{* * *}$ indicates significance at the 10, 5, and 1-percent levels, respectively.

\subsection{Ownership structure}

Three facets of a firm's ownership structure are analyzed in the following: concentration of ownership, complexity of ownership, and the type of the shareholder that is in ultimate control. First, Table 6 describes how ownership concentration differs between firms that survive, fail, or are acquired. In analogy to the tables in Sections 4.2 and 4.3, mean (columns 1-3) and median (columns 4-6) statistics are reported for different time horizons, ranging from looking one year ahead to looking four or more years ahead.

Table 6 shows that ownership concentration of firms that are acquired and firms that fail is significantly below ownership concentration of firms that survive. For example, concentration as measured by the Herfindahl index is, on average, 51.2 percent for firms one year before they fail, 60.4 percent for firms one year before they are acquired, but 67.6 percent for firms that survive the following year. The difference to surviving firms is 
Table 6: Ownership concentration as determinant of exit

\begin{tabular}{|c|c|c|c|c|c|c|c|}
\hline & \multicolumn{3}{|c|}{ Mean } & \multicolumn{3}{|c|}{ Median } & \multirow{2}{*}{$\begin{array}{r}\text { Number } \\
\text { of obs. }\end{array}$} \\
\hline & Survival & Failure & Acquisition & Survival & Failure & Acquisition & \\
\hline \multicolumn{8}{|c|}{ Ownership concentration (Herfindahl index) } \\
\hline within 4 years + & $64.9 \%$ & $46.2 \% * * *$ & $55.5 \% * * *$ & $73.3 \%$ & $36.0 \% * * *$ & $56.3 \% * * *$ & 3.283 \\
\hline within 3 years & $64.5 \%$ & $49.9 \% * * *$ & $55.8 \% * * *$ & $70.6 \%$ & $39.4 \% * * *$ & $56.3 \% * * *$ & 4,049 \\
\hline within 2 years & $66.5 \%$ & $50.8 \% * * *$ & $59.6 \% * * *$ & $81.0 \%$ & $41.5 \% * * *$ & $59.9 \% * * *$ & 5,331 \\
\hline within 1 year & $67.6 \%$ & $51.2 \% * *$ & $60.4 \% * * *$ & $84.6 \%$ & $46.9 \% * * *$ & $62.5 \%$ *** & 6,515 \\
\hline
\end{tabular}

Notes: Mean and median values of ownership concentration, calculated for firms which survive or exit within the next one to four or more years. The test statistics are heteroskedastic t-tests of equal means (columns 1 vs. 2 , and 1 vs. 3 ) and Wilcoxon rank-sum tests of equal medians (columns 4 vs. 5 , and 4 vs. 6). ${ }^{*}, * *, * * *$ indicates significance at the 10, 5, and 1-percent levels, respectively.

highly significant, irrespective of the time horizon considered. For a time horizon of four or more years, the difference in ownership concentration between failures and acquisitions is also significant at the one-percent level (not tabled). Hence, the evidence supports Hypothesis F4, but not Hypothesis A4.

Table 7 differs from Tables 4-6 because the variables used to describe the complexity of ownership and the type of firms' ultimate owner are dummy variables. Since in this case median statistics can take only the values of zero or one, they would be of little help when comparing firms by their survival status. Therefore, Table 7 reports only mean values. These mean statistics represent the fraction of firms for a given time horizon for which the respective ownership characteristic is true.

The first two variables in Table 7 describe pyramids and cross-ownership, two elements of the ownership structure that can increase its complexity. We find that a significantly smaller fraction of failing firms is part of a pyramid compared with surviving firms. For example, 22.6 percent of firms that fail within one year are part of a pyramid structure, compared to more than 50 percent of firms that survive at least one more year. Likewise, failing firms are also less likely to be controlled by an owner which is part of the web of large financial and non-financial German companies (Adams, 1994; Wenger and Kaserer, 1998). In fact, the fraction of failing firms that are cross-owned is zero. For firms that are acquired, the fraction of firms being part of a pyramid or controlled by a cross-owned shareholder is significantly lower than among surviving firms, but only for a time horizon of four or more years. In sum, the results on the complexity of ownership strongly suggest that pyramids and cross-ownership can help avert firm failure (Hypothesis F5) and, to a weaker extent, also acquisition by another entity (Hypothesis A5).

In addition, we also collected information on the type of the ultimate owner of each firm. There are five types of shareholders: private, financial, non-financial, government, and dispersed. In the latter case, no single dominant shareholder is identified when applying the concept of control as described in Appendix B. Hence, Table 7 also examines whether firms under a specific type of ultimate owner are more likely to fail or to be acquired. 
Table 7: Ownership type as determinant of exit

\begin{tabular}{|c|c|c|c|c|}
\hline & \multicolumn{3}{|c|}{ Mean of group } & \multirow{2}{*}{$\begin{array}{r}\text { Number } \\
\text { of obs. }\end{array}$} \\
\hline & Survival & Failure & Acquisition & \\
\hline $\begin{array}{l}\text { Fraction of firms } \\
\text { within } 4 \text { years }+ \\
\text { within } 3 \text { years } \\
\text { within } 2 \text { years } \\
\text { within } 1 \text { year }\end{array}$ & $\begin{array}{c}\text { eing part } \\
43.7 \% \\
43.3 \% \\
47.5 \% \\
50.6 \%\end{array}$ & $\begin{array}{l}\text { of pyramid } \\
23.0 \% * * * \\
29.3 \% * * \\
25.9 \% * * * \\
22.6 \% * * *\end{array}$ & $\begin{array}{l}36.7 \% \text { *** } \\
43.6 \% \\
48.8 \% \\
50.5 \%\end{array}$ & $\begin{array}{l}3,283 \\
4,049 \\
5,331 \\
6,515\end{array}$ \\
\hline $\begin{array}{l}\text { Fraction of firms } \\
\text { within } 4 \text { years }+ \\
\text { within } 3 \text { years } \\
\text { within } 2 \text { years } \\
\text { within } 1 \text { year }\end{array}$ & $\begin{array}{r}\text { ontrolled } \\
9.0 \% \\
8.1 \% \\
8.1 \% \\
8.0 \%\end{array}$ & $\begin{array}{l}\text { cross-ow1 } \\
0.0 \% * * * \\
0.0 \% * * \\
0.0 \% * * \\
0.0 \% *\end{array}$ & $\begin{array}{l}\text { ed firm } \\
\qquad .8 \% * * * \\
6.6 \% \\
6.8 \% \\
5.7 \%^{*}\end{array}$ & $\begin{array}{l}3,283 \\
4,049 \\
5,331 \\
6,515\end{array}$ \\
\hline $\begin{array}{l}\text { Type of ultimate } \\
\text { within } 4 \text { years }+ \\
\text { within } 3 \text { years } \\
\text { within } 2 \text { years } \\
\text { within } 1 \text { year }\end{array}$ & $\begin{array}{r}40.3 \% \\
39.4 \% \\
36.1 \% \\
33.8 \%\end{array}$ & $\begin{array}{l}\text { viduals } \\
68.3 \% * * * \\
64.0 \% * * * \\
63.0 \% * * * \\
54.8 \% * *\end{array}$ & $\begin{array}{l}30.3 \%^{* * *} \\
28.8 \%^{* * *} \\
28.4 \%^{* * *} \\
25.8 \%^{* * *}\end{array}$ & $\begin{array}{l}3,283 \\
4,049 \\
5,331 \\
6,515\end{array}$ \\
\hline $\begin{array}{l}\text { Type of ultimate } \\
\text { within } 4 \text { years }+ \\
\text { within } 3 \text { years } \\
\text { within } 2 \text { years } \\
\text { within } 1 \text { year }\end{array}$ & $\begin{array}{r}10.1 \% \\
9.2 \% \\
8.8 \% \\
8.5 \%\end{array}$ & $\begin{array}{l}\text { ncial firm } \\
0.0 \% * * * \\
0.0 \% * * * \\
0.0 \% * * \\
3.2 \%\end{array}$ & $\begin{array}{l}6.0 \% * * * \\
7.8 \% \\
7.1 \% \\
6.2 \%^{*}\end{array}$ & $\begin{array}{l}3,283 \\
4,049 \\
5,331 \\
6,515\end{array}$ \\
\hline $\begin{array}{l}\text { Type of ultimate } \\
\text { within } 4 \text { years }+ \\
\text { within } 3 \text { years } \\
\text { within } 2 \text { years } \\
\text { within } 1 \text { year }\end{array}$ & $\begin{array}{c}35.8 \% \\
37.2 \% \\
39.8 \% \\
41.1 \%\end{array}$ & $\begin{array}{l}\text {-financial fi } \\
17.3 \% * * * \\
16.0 \% * * * \\
18.5 \% * * * \\
25.8 \% *\end{array}$ & $\begin{array}{l}\mathrm{m} \\
40.2 \% * * \\
38.4 \% \\
39.3 \% \\
40.2 \%\end{array}$ & $\begin{array}{l}3,283 \\
4,049 \\
5,331 \\
6,515\end{array}$ \\
\hline $\begin{array}{l}\text { Type of ultimate } \\
\text { within } 4 \text { years }+ \\
\text { within } 3 \text { years } \\
\text { within } 2 \text { years } \\
\text { within } 1 \text { year }\end{array}$ & $\begin{array}{r}10.3 \% \\
11.0 \% \\
11.2 \% \\
11.5 \%\end{array}$ & $\begin{array}{l}\text { ersed share } \\
10.8 \% \\
16.0 \% \\
14.8 \% \\
12.9 \%\end{array}$ & $\begin{array}{l}22.7 \% * * * \\
23.7 \% * * * \\
20.8 \% * * * \\
21.3 \% * * *\end{array}$ & $\begin{array}{l}3,283 \\
4,049 \\
5,331 \\
6,515\end{array}$ \\
\hline $\begin{array}{l}\text { Type of ultimate } \\
\text { within } 4 \text { years }+ \\
\text { within } 3 \text { years } \\
\text { within } 2 \text { years } \\
\text { within } 1 \text { year }\end{array}$ & $\begin{array}{r}\text { wwner: gov } \\
3.5 \% \\
3.2 \% \\
4.1 \% \\
5.0 \%\end{array}$ & $\begin{array}{c}\text { ernment } \\
3.6 \% \\
4.0 \% \\
3.7 \% \\
3.2 \%\end{array}$ & $\begin{array}{l}0.8 \%^{* * *} \\
1.2 \%^{* * *} \\
4.3 \% \\
6.5 \%\end{array}$ & $\begin{array}{l}3,283 \\
4,049 \\
5,331 \\
6,515\end{array}$ \\
\hline
\end{tabular}

Notes: Fraction of firms for which ownership characteristic is true, calculated for firms that survive or exit within the next one to four or more years. The test statistics are calculated as two-sided tests on the equality of proportions (columns 1 vs. 2 , and 1 vs. 3 ). ${ }^{*},{ }^{* *}$, *** indicates significance at the 10, 5, and 1-percent levels, respectively. 
Table 7 shows that the largest fraction of failing firms is controlled by a large private shareholder. This fraction is significantly higher than the fraction of surviving firms under private control. One explanation could be that private shareholders are more wealthconstrained, and therefore firms under private control could suffer from low liquidity. In turn, a comparatively low fraction of failing firms is controlled by a financial or a non-financial firm. For example, 17.3 percent of firms that are ultimately owned by a non-financial firm fail within the next four or more years. The respective fraction of firms that survive four or more years is more than two times higher (35.8 percent). This result is consistent with considerations on internal capital markets. For example, Lamont (1997) shows for the US oil industry that internal capital markets are often used to transfer cash flow between divisions. Hence, firms under control of a corporate shareholder could be less likely to be wealth-constrained. Furthermore, we find that a significantly larger fraction of firms with no dominant owner (dispersed) are acquired than survive. In turn, a comparatively low fraction of firms are acquired which are under the control of a large private owner. This finding again supports Holmström and Tirole (1993) because ownership concentration appears to be negatively related to the likelihood of an acquisition. Finally, there is some evidence that the likelihood to be acquired is lower than the likelihood to survive for firms under control of a financial firm, and higher for firms under control of a non-financial firm. This finding supports the notion that German financial firms are cross-owned, and firms with complex ownership structures are less likely to be acquired (Hypothesis A5).

In summary, the results presented in Tables 6 and 7 indicate that not only concentration of shares matters. Also the complexity of indirect ownership structures and the type of the ultimate shareholder appear to be relevant for whether a firm is likely to fail or to be acquired. For a more technical analysis of failure and acquisition in a multivariate analysis this implies that not only ownership concentration should be included as explanatory variable, but also more detailed owner-specific measures such as ownership type and ownership complexity. However, typically these owner-specific measures are not easily accessible, but must be constructed on a firm-by-firm basis. Finally, we find that the length of the time horizon considered is not likely to have a significant impact on results.

\subsection{Restructuring and firm size}

As a last set of potential determinants of firm failure and acquisition we consider restructuring activity and firm size. Table 8 is structured in analogy to Tables 4-6 and shows mean (columns 1-3) and median (columns 4-6) statistics calculated for different time horizons, ranging from looking one year ahead to looking four or more years ahead, separately for firms that survive, fail, or are acquired.

Restructuring activity, if measured by the annual growth rate of employment, is more extensive in failing firms than in surviving firms. For example, firms that fail within one year cut employment by 11.2 percent, but firms that survive at least one more year increase employment by 1.9 percent. Likewise, firms which are acquired show decreasing employment. But the growth rates of employment for acquired firms and surviving firms are significantly different only at the median, not at the mean. However, failing and acquired firms are significantly different in terms of employment growth at the one-percent level, both at the mean and at the median. When restructuring is measured by the fraction of fixed assets sold per year, there is also evidence that restructuring activity is more 
Table 8: Restructuring and firm size as determinants of exit

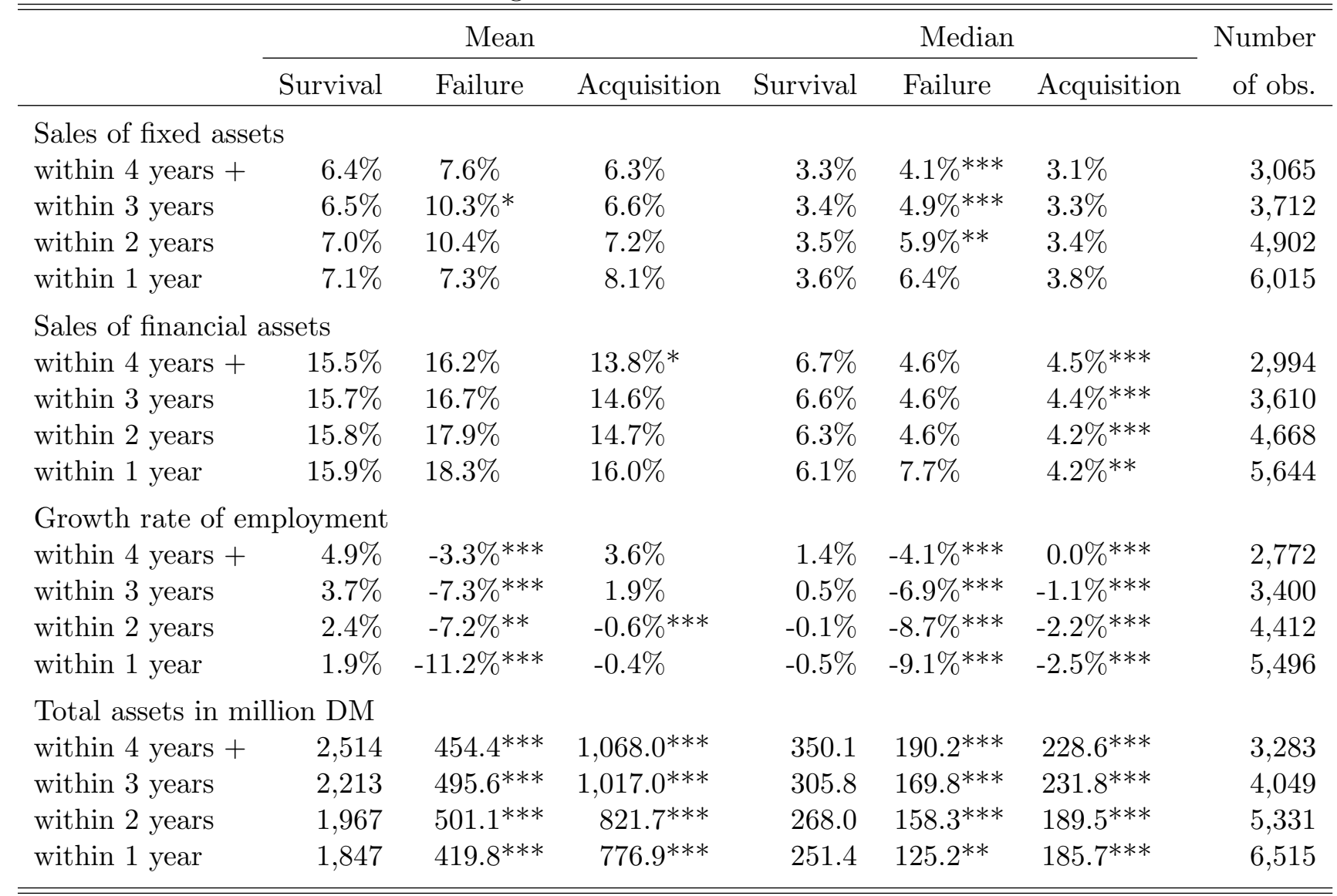

Notes: Mean and median values of restructuring and firm size measures, calculated for firms which survive or exit within the next one to four or more years. The test statistics are heteroskedastic t-tests of equal means (columns 1 vs. 2, and 1 vs. 3) and Wilcoxon rank-sum tests of equal medians (columns 4 vs. 5 , and 4 vs. 6 ). ${ }^{*}, * *, * * *$ indicates significance at the 10 , 5 , and 1-percent levels, respectively.

extensive in failing firms because assets are sold at a higher rate compared with surviving firms. In contrast, sales of financial assets are, at least at the median, significantly lower in firms that are about to experience an acquisition compared with surviving firms. In summary, there is evidence supporting Hypothesis F3 and Hypothesis A3, and this evidence is weaker when restructuring is measured using the sales rate of assets than when using the growth rate of employment.

Finally, there is strong evidence in favor of Hypothesis F6 and Hypothesis A6. Firms that survive at least one more year show average total assets of about 1,800 million DM. This compares to total assets of about 420 million DM for firms that fail, and about 780 million DM for firms that are acquired within one year. These differences are found across all four time horizons, and also for other measures of firm size such as total sales and the number of employees (not tabled). Generally, the difference between failing and acquired firms is significant at the one-percent level (not tabled). In sum, firms that are acquired are approximately half as large as surviving firms, and firms that fail are about half as large as acquired firms. This indicates that firm size can reduce the likelihood of acquisition and failure.

Concerning the question how to measure firm size, we find that total assets, total sales, or the number of employees yield similar results. Since in our data set the number of 
missing observations is the smallest for total assets, we prefer this measure of firm size. Again, the length of the time horizon does not play a role. Regarding restructuring, our measures yield different results, depending on the measure chosen. As Table 8 shows, the growth rate of employment appears to be related to the likelihood of acquisition and failure. Therefore, a measure of layoff activity looks more promising when to be used as explanatory variable in a multivariate analysis.

\subsection{Comparison of different explanatory variables}

The literature review in Section 2 suggests that performance, capital structure, ownership structure as well as firm size and restructuring activity are important determinants of acquisition and failure of firms. In general, this is confirmed by the descriptive evidence presented in Sections 4.2-4.5. However, the descriptive evidence also suggests that the power of firm characteristics to explain failure and acquisition in a multivariate framework is likely to depend on the specific measure chosen. For performance, accounting measures such as industry-adjusted ROA and industry-adjusted total factor productivity seem to be the most helpful. For capital structure, the debt-to-assets ratio and interest coverage look promising, and for restructuring activity and firm size, the growth rate of employment and the natural logarithm of total assets, respectively. Finally, the evidence on ownership structure suggests that not only concentration of shares is relevant. In addition, information on the complexity of ownership, as reflected in pyramids and cross-ownership, and information on the type of the ultimately controlling shareholder should enter any model that attempts to explain corporate failure or acquisition.

Regarding the question which length of time horizon to consider in a multivariate analysis, the evidence suggests that regression results should not much be affected by the choice of a particular time horizon. This is an important finding because the explanatory power of regressions with a time horizon of one year, and hence with a larger number of observations, will be significantly greater. For our sample, the sample with a one-year time horizon is about twice as large as the sample with a four-year time horizon.

\section{Conclusions}

This study provides new stylized facts on the determinants of corporate acquisition and failure in Germany. In that course, it has important implications for the design of empirical studies. In particular, we identify which firm-specific characteristics are helpful to explain corporate acquisition and failure, and which measures of these characteristics have the highest explanatory power. We also examine to what extent the length of the forwardlooking time horizon affects the usefulness of our explanatory variables. But we do not examine these issues in a multivariate framework. For a first application of our findings using a more technical analysis see Heiss and Köke (2001).

The analysis is based on a sample of about 1,700 medium-sized and large German firms for the years 1986-1995. We include listed as well as non-listed firms. Evidence based on descriptive statistics identifies the following firm-specific characteristics as useful to explain acquisition and failure, with suitable measures of these characteristics reported in parentheses: performance (industry-adjusted return-on-assets and industry-adjusted total factor productivity), capital structure (debt-to-assets ratio), ownership concentration 
(Herfindahl index), ownership complexity (cross-ownership and pyramids), restructuring activity (growth rate of employment), and firm size (total assets). In addition, information on the type of the ultimately controlling shareholder turns out to be important.

Our analysis yields a number of new stylized facts. First, in large and medium-sized German firms poor performance and high financial pressure appears to make failure and acquisition more likely. This contrasts with a view often heard in Germany that topperforming firms would be the most likely to become takeover targets. Rather, our descriptive evidence is consistent with studies on the US that takeover targets are poor performers (Altman, 1968; Powell, 1997; Denis and Sarin, 1999; Maksimovic and Phillips, 2000). Second, compared with surviving firms, ownership is much less concentrated in firms that fail or are acquired. For acquisitions, this is in line with Holmström and Tirole (1993) who predict that capital markets will be able to determine the necessity of a takeover only as long as concentration does not become too large. For failure, this could be explained with large shareholders alleviating the agency problem via better monitoring (Shleifer and Vishny, 1986). Third, firm size and cross-ownership seem to act as a kind of takeover deterrent. Firms that are acquired are significantly smaller in size and more likely to be under control of a cross-owned shareholder. These findings are in line with theoretical predictions (Shleifer and Vishny, 1992; Bebchuk et al.; 1998). Similarly, larger firms and firms that are part of pyramid structures or are controlled by a cross-owned shareholder are also less likely to fail. Fourth, firms that are about to fail or to be acquired show significantly higher restructuring activity, measured as employee layoffs, compared with surviving firms.

This study has important implications for the design of empirical studies explaining corporate failure or acquisition. First, failure and acquisition typically are the two main reasons for sample attrition in empirical studies, and they appear to be influenced by common factors. Hence, they should be examined in combination. Models explaining failure but not taking into account the second form of sample exit, acquisition (see, e.g., Harhoff et al., 1998; Almus, 2000), or vice versa, are likely to suffer from a sample selection problem. This could bias estimation results (Börsch-Supan and Köke, 2000). Second, we find that the industry distribution is significantly different for failure and acquisitions. This calls for some kind of industry adjustment in the empirical analysis, for example by including industry dummies or by correcting some variables for their industry benchmark. Third, a range of firm-specific characteristics is helpful to explain failure and acquisition. Analyses leaving out some of these measures are potentially subject to the classical omitted variables problem. Fourth, care should be taken when selecting specific measures for these firm characteristics because some measures perform much better than others in the analysis of firm exit. Finally, the good news is that the length of the forward-looking time horizon essentially does not seem to matter for the usefulness of our measures. This implies that regression models using shorter lags should capture the main effects. 


\section{References}

Adams, M. (1994), Die Usurpation von Aktionärsbefugnissen mittels Ringverpflechtung in der "Deutschland AG", Die Aktiengesellschaft 4, 148-158.

Almus, M. (2000), The Shadow of Death: An Empirical Analysis of the Pre-Exit Performance of Young German Firms, Unpublished Manuscript, ZEW Discussion Paper 00-44, Centre for European Economic Research, Mannheim (ZEW).

Altman, E. (1968), Financial Ratios, Discriminant Analysis, and the Prediction of Corporate Bankruptcy, Journal of Finance 23, 589-609.

Astebro, T. and J. Winter (2001), More Than a Dummy: The Probability of Survival, Failure, and Acquisition of Firms in Financial Distress, Unpublished Manuscript, University of Waterloo and University of Mannheim.

Barcley, M.J. and C.G. Holderness (1991), Negotiated Block Trades and Corporate Control, Journal of Finance 46, 861-878.

Bebchuk, L.A. (1994), Efficient and Inefficient Sales of Corporate Control, Quarterly Journal of Economics 109, 957-993.

Bebchuk, L., R. Kraakman and G. Triantis (1998), Stock Pyramids, Cross-Ownership, and Dual Class Equity: The Creation and Agency Costs of Separating Control From Cash Flow Rights, Unpublished Manuscript, NBER No. 6951, Cambridge/MA.

Bethel, J.E., J.P. Liebeskind and T. Opler (1998), Block Share Purchases and Corporate Performance, Journal of Finance 53 (2), 605-634.

Böhmer, E. (2000), Industry Groups, Bank Control, and Large Shareholders: An Analysis of German Takeovers, Journal of Financial Intermediation 9 (2), 117-148.

Börsch-Supan, A. and J. Köke (2000), An Applied Econometrician's View of Empirical Corporate Governance Studies, ZEW Discussion Paper 00-17, Centre for European Economic Research, Mannheim (ZEW).

Burkart, M., D. Gromb and F. Panunzi (2000), Agency Conflicts in Public and Negotiated Transfers of Corporate Control, Journal of Finance 55 (2), 647-677.

Denis, D.J. and A. Sarin (1999), Ownership and Board Structures in Publicly Traded Corporations, Journal of Financial Economics 52, 187-223.

Franks, J. and C. Mayer (1994), The Ownership and Control of German Corporations, Unpublished Manuscript, London Business School, London, and University of Oxford, Oxford.

Franks, J. and C. Mayer (1995), Ownership and Control, in: H. Siebert (ed.), Trends in Business Organization, Tübingen: Mohr, 171-200.

Franks, J. and C. Mayer (1998), Bank Control, Takeovers and Corporate Governance in Germany, Journal of Banking and Finance 22, 1385-1403.

Franks, J., C. Mayer and L. Renneboog (1999), Who Disciplines Bad Management?, Unpublished Manuscript, Oxford Financial Research Centre, Oxford. 
Grossman, S.J. and O.D. Hart (1980), Takeover Bids, the Free-Rider Problem, and the Theory of the Corporation, Bell Journal of Economics 11, 42-64.

Hanley, K. and W. Wilhelm (1995), Evidence on the Strategic Allocation of Initial Public Offerings, Journal of Financial Economics 37, 239-257.

Harhoff, D., K. Stahl and M. Woywode (1998), Legal Form, Growth and Exit of West German Firms: Empirical Results For Manufacturing, Construction, Trade and Service Industries, Journal of Industrial Economics 46 (4), 453-488.

Heiss, F. and J. Köke (2001), Dynamics in ownership and firm survival: Evidence from corporate Germany, ZEW Discussion Paper, forthcoming, Centre for European Economic Research, Mannheim (ZEW).

Holmström, B. and J. Tirole (1993), Market Liquidity and Performance Monitoring, Journal of Political Economy 101 (4), 679-709.

Jenkinson, T. and A. Ljungqvist (2001), The Role of Hostile Stakes in German Corporate Governance, Journal of Corporate Finance, forthcoming.

Jensen, M.C. (1986), Agency Costs of Free Cash Flow, Corporate Finance and Takeovers, American Economic Review 76, 323-329.

Kahan, M. (1993), Sales of Corporate Control, Journal of Law, Economics, and Organization 9, 368-379.

Köke, J. (2000), Control Transfers in Corporate Germany: Their Frequency, Causes, and Consequences, Unpublished Manuscript, ZEW Discussion Paper 00-67, Centre for European Economic Research, Mannheim (ZEW).

Köke, J. (2001), New Evidence on Ownership Structures in Germany, Kredit und Kapital, $2,1-36$.

Lamont, O. (1997), Cash Flow and Investment: Evidence from Internal Capital Markets, Journal of Finance 52, 83-110.

La Porta, R., F. Lopez-de-Silanes and A. Shleifer (1999), Corporate Ownership Around the World, Journal of Finance 54 (2), 471-517.

Maksimovic, V. and G. Phillips (2000), The Market for Corporate Assets: Who Engages in Mergers and Asset Sales and Are There Efficiency Gains?, Unpublished Manuscript, University of Maryland.

Mitchell, M.L. and J.H. Mulherin (1996), The Impact of Industry Shocks on Takeover and Restructuring Activity, Journal of Financial Economics 41, 193-229.

Mello, A.S. and J.E. Parsons (1998), Going Public and the Ownership Structure of the Firm, Journal of Financial Economics 49, 79-109.

Mulherin, J.H. and A.L. Boone (2000), Comparing Acquisitions and Divestitures, Journal of Corporate Finance 6, 117-139.

Powell, R.G. (1997), Modelling Takeover Likelihood, Journal of Business Finance and Accounting 24, 1009-1030. 
Renneboog, L. (2000), Ownership, Managerial Control and the Governance of Companies Listed on the Brussels Stock Exchange, Journal of Banking and Finance 24 (12), 1959-1995.

Shleifer, A. and R.W. Vishny (1986), Large Shareholders and Corporate Control, Journal of Political Economy 94 (3), 461-488.

Shleifer, A. and R.W. Vishny (1992), Liquidation Values and Debt Capacity: A Market Equilibrium Approach, Journal of Finance 47, 1343-1366.

Shumway, T. (2001), Forecasting Bankruptcy More Accurately: A Simple Hazard Rate Model, Journal of Business 74, 101-124.

Wagner, J. (1999), The Life History of Cohorts of Exits From German Manufacturing, Small Business Economics 13, 71-79.

Wenger, E. and C. Kaserer (1998), The German system of corporate governance - a model which should not be imitated, in: S.W. Black and M. Moersch (Eds.), Competition and Convergence in Financial Markets, Amsterdam: Elsevier, 41-78.

Zingales, L. (1998), Survival of the Fittest or the Fattest? Exit and Financing in the Trucking Industry, Journal of Finance 53 (3), 905-938. 


\section{A Data sources and sample selection}

The starting point of data selection is Hoppenstedt's Balance Sheet Database (BSD) which contains information on a significant number of large listed and non-listed firms, both in the legal form of AG and GmbH. We take 1986 as the starting year because a change in disclosure rules hinders comparability of the annual reports before and after the year $1986 .^{2}$ The last year of our investigation is 1996 because our series of ownership data ends in this year. For the period 1986-1996, BSD contains 5,679 firms (31,294 firmyears) for which consolidated balance sheet data are available. We eliminate firms from the utility, traffic, and telecommunications industries because they were still predominantly government-owned during the period of observation. As a matter of comparability, we also eliminate firms which primarily operate in the banking and insurance business, while operating little in non-financial activities. In combination, selection by industry causes 1,928 firm deletions.

Data on ownership structures are obtained from annual reports published by former Hypobank. These reports contain ownership information on all listed German companies, but also on a range of large non-listed firms. Hypobank reports the size and the name of a direct owner when the size of the ownership block exceeds five percent. In very few cases smaller ownership blocks are also included. However, ownership information from Hypobank cannot readily be used in our analysis for three reasons. First, ownership information from Hypobank only refers to the direct level of owners. But this analysis requires to identify the ultimate owner of each sample firm. Second, Hypobank does not directly reveal ownership information on medium-sized non-listed firms. Other commercial data sources are also of little help because during our period of observation, non-listed firms generally have not been subject to strictly enforced disclosure requirements. Therefore, we construct the relevant ownership structures by searching the information on investments in subsidiaries and affiliated companies which is given in the appendix to each company in Hypobank. In addition, we searched the Mannheim Company Database (MUP) located at the ZEW in Mannheim. Thereby we obtain ownership structures on many mediumsized non-listed firms, mainly in the legal form of private companies with limited liability (GmbH). Third, we tracked all sample firms through the years 1986-1996 to obtain a panel on ownership structures, merging firm-years on the basis of the name of each company. A problem was that some firms in our sample changed their names during the period of observation, for example following takeovers or restructuring of conglomerates. Since changes in ownership are crucial to the data collection procedure, we searched Hypobank and MUP for information on changes in names as well as takeovers.

In sum, we drop firms with less than two consecutive years for which ownership information is available because our analysis requires to calculate changes in ownership (2,216 firm deletions). And 71 firms must be eliminated due to missing values on the variables used for the empirical analysis. This selection procedure leaves 1,464 firms (6,541 firm-years) for the years 1986-1996. Table 9 summarizes the selection procedure.

To construct the final sample required for the analysis of firm survival, failure, and acquisition, we proceed in three steps. First, we examine all firms (241 firms) for which balance sheet data end before 1996, the final year of the sample, because these represent

2 In 1985 several changes were introduced in German corporate law (§289HGB), most of them triggered by the European Community's Fourth Company Law Directive on the harmonization of national requirements pertaining to financial statements. 
Table 9: Data selection procedure

\begin{tabular}{lrr}
\hline \hline Selection criterion & Firms & Firm-years \\
\hline Consolidated balance sheet data for the years 1986-1996 & 5,679 & 31,294 \\
Mining, manufacturing, construction, and trade & 3,751 & 20,614 \\
Two consecutive years of ownership data & 1,535 & 9,000 \\
No missing values & 1,464 & 6,541 \\
\hline Splitting of time series in case of acquisition & 1,676 & 6,541 \\
Two forms of market exit: acquisition and bankruptcy & 1,670 & 6,515 \\
\hline \hline
\end{tabular}

potential firm exits. In particular, we check the consistency of information on the reason for exit provided in BSD and MUP databases. In addition, all relevant firms have been contacted by telephone.

In a second step, firm's ownership structures are examined to identify changes in control. If the name of the ultimate owner changes, this is interpreted as an acquisition. ${ }^{3}$ Hence, a firm as reported in BSD could experience several exits during the sample period. However, this does not occur often. For 1,1103 firms (75.3 percent), ultimate ownership remains constant during the full sample period. For 309 firms (21.1 percent), the ultimate owner changes once, for 45 firms (3.1 percent) twice, and for 7 firms (0.5 percent) three times.

Summarizing, firm exit can occur in two forms: (1) failure or acquisition, reflected in an interrupted balance sheet data time series as provided by BSD, and (2) acquisition, reflected in an ongoing balance sheet data time series but a change in ultimate ownership. Applying this definition of exit to our sample, the number of 1,464 firms increases to 1,676 firms. The number of observations (6,541 firm-years), of course, remains constant.

In a final step, we eliminate six firms (26 firm-years) that shut down operations but did not declare bankruptcy because the determinants of voluntary and forced exit are eventually different. If this is true, our findings on the determinants of forced exit will (statistically) be more difficult to identify. This leaves a final sample of 1,670 firms $(6,515$ firm-years). We refer to this as the full sample in the empirical analysis in Section 4. It includes only firm-years for which we know whether the particular firm is acquired, declares bankruptcy, or survives in the year ahead. In this case, the time horizon is one year. The full sample excludes all firm-years for which the survival status one year ahead is unknown and firm-years in which an acquisition takes place. In addition, three subsamples are used in the empirical analysis with time horizons of two (5,331 firm-years), three (4,049 firm-years), and four or more years (3,283 firm-years). Since this requires a spell length of at least two, three, or four and more years, the number of observations is lower the longer the time horizon is (see also Section 3).

\section{B Concept of control}

Large German companies typically show complex ownership structures such as pyramids with several layers of ownership and cross-ownership between firms (La Porta et al., 1999;

3 Appendix B provides a technical description of the concept of control applied in this study (see also Köke, 2000). 
Böhmer, 2000; Köke, 2001). Hence, analysis of direct ownership is not sufficient. It is important to determine which shareholder ultimately controls a firm (ultimate ownership). This requires considering the ownership structure of direct shareholders as well as a criterion that establishes whether a shareholder is controlled by another shareholder, i.e. whether to extend the analysis to the next level in the ownership structure. In essence, for each shareholder in any control chain it needs to be established whether there is a controlling owner or not.

The ultimate owner is identified for each firm in two steps. First, we identify the ultimate owner of each direct shareholder using the following rules: Starting from the direct level (level 1), we proceed to the next level (level 2) in the ownership structure if the largest shareholder on level 2 owns 50 percent or more of the shares. If this criterion is not met, the largest shareholder must own 25 percent or more of the shares, with all other shareholders owning less than 25 percent. In case where both criteria are not met, our stop rule applies and we do not pursue the respective ownership chain further. These rules guarantee that no more than one ultimate owner is identified for each direct shareholder. Note that if a shareholder has split his ownership stake in a particular company into several smaller stakes, for example into two blocks of 50 percent held by two subsidiary firms, we combine these smaller stakes into one single block. We set the first cut-off point at 50 percent because German law allows an investor owning 50 percent or more of all company shares to appoint management. ${ }^{4}$ The second cut-off point is set at 25 percent because an investor owning 25 percent of the shares in a company has the right to veto decisions. In a second step in determining the ultimate owner, we apply both rules to all direct shareholders. This allows us to identify one single shareholder that is in ultimate control of each sample firm. When no single shareholder fulfills the criteria of our concept of control, this company is seen to have no ultimate owner.

4 A 50 percent majority is sufficient to dismiss management after their regular period of office. But a majority of 75 percent is required to dismiss management during its period of office (§103(1)AktG). 


\section{Definition of variables}

Table 10: Definition of variables

\section{Performance:}

Total factor productivity

Return-on-assets (ROA)

Return-on-equity (ROE)

Return-on-sales (ROS)

Market-to-book ratio

Stock market return
Residual from OLS estimation of Cobb-Douglas production function, $y=\alpha k+\beta l$, with $\mathrm{y}=\ln$ (total sales), $\mathrm{k}=\ln$ (replacement costs of tangible assets) and $l=\ln$ (total number of employees). Sales and capital stock are deflated using appropriate price indices.

Earnings before interest and taxes (EBIT) divided by total assets EBIT divided by total equity

EBIT divided by total sales

Market value of equity divided by book value of equity

Continuous yearly return $R_{t}^{c}=\sum_{w=1}^{n} \frac{R_{w}^{c}}{n} * 52$ with continuous weekly return $R_{w}^{c}=\ln \left(\frac{K_{w}^{p}}{K_{w-1}^{p}}\right)$ with $K_{w}^{p}$ performance value on Wednesday of week w. $K_{w}^{p}$ is corrected for capital changes, changes of stock's face value, stock splits, and dividend payments.

Ownership structure:

Herfindahl index

Control

Pyramid

Cross-ownership

$H=\sum_{j=1}^{n} P_{j}$, with $P_{j}$ size of individual block

Control $=1$ if firm has ultimately controlling shareholder, calculated based on concept of control, zero otherwise Pyramid $=1$ if ultimately controlling shareholder is located on the second or higher level in the ownership structure, zero otherwise Cross $=1$ if ultimate owner is part of the web of firms identified by Wenger and Kaserer (1997) and if ultimate owner indirectly owns share block in itself, zero otherwise

Capital structure:

Debt-to-assets ratio

Interest coverage

Working capital ratio

Quick ratio

Cash-flow-to-assets

Total debt to total assets

EBIT divided by interest payments

Short-term assets less short-term liabilities divided by total assets

Short-term assets less short-term liabilities less inventory divided by total assets

(EBIT+depreciation+taxes) divided by total assets

\section{Restructuring:}

Sales of assets $s_{j t}=\frac{S_{j t}}{T_{j t}}$ with $S_{j t}$ sales of asset class $\mathrm{j}$ in year $\mathrm{t}$ and $T_{j t}$ stock of asset class $\mathrm{j}$ at the beginning of year $\mathrm{t}$

Growth rate of $n_{t}=\frac{N_{t}-N_{t-1}}{N_{t-1}}$ with $N_{t}$ total number of employees in year $\mathrm{t}$ 